\title{
An interleukin-1 receptor antagonist protein protects insulin-producing Beta cells against suppressive effects of interleukin-1 $\beta$
}

\author{
D.L.Eizirik ${ }^{1}$, D.E. Tracey ${ }^{2}$, K. Bendtzen ${ }^{3}$ and S.Sandler ${ }^{1}$ \\ ${ }^{1}$ Department of Medical Cell Biology, Uppsala University, Uppsala, Sweden \\ 2 Hypersensitivity Diseases Research, The Upjohn Company, Kalamazoo, Michigan, USA, and \\ ${ }^{3}$ Laboratory of Medical Immunology, Medical Department TTA, University Hospital, Copenhagen, Denmark.
}

\begin{abstract}
Summary. The cytokine interleukin-1 $\beta$ may have an important role in the autoimmune mediated damage of pancreatic Beta cells in insulin-dependent diabetes mellitus. In the present study we have investigated the effects of an interleukin-1 receptor antagonist protein, a blocker of the type I interleukin-1 receptor, on the suppressive actions of recombinant interleukin- $1 \beta$ on insulin-producing cells. Brief exposure (1$2 \mathrm{~h}$ ) of rat and mouse pancreatic islets to $10 \mathrm{ng} / \mathrm{ml}$ recombinant interleukin- $1 \beta$ induced an $70-80 \%$ inhibition of insulin response to glucose after $12 \mathrm{~h}$. These effects were completely counteracted by co-incubation with $100 \mathrm{ng} / \mathrm{ml}$ interleukin-1 receptor antagonist protein. When rat islets were cultured for $48 \mathrm{~h}$ in the presence of recombinant interleukin- $1 \beta(5 \mathrm{ng} / \mathrm{ml})$
\end{abstract}

higher concentrations of interleukin-1 receptor antagonist protein $(5000 \mathrm{ng} / \mathrm{ml})$ were required to protect Beta-cell function. Interleukin-1 receptor antagonist protein also counteracted the inhibitory effects of recombinant interleukin- $1 \beta$ on the growth of the rat insulinoma cell line RINm5F. These data suggest that interleukin-1 receptor antagonist protein can protect insulin-producing cells from the deleterious effects of recombinant interleukin- $1 \beta$, and that these cells possess type I interleukin- 1 receptors.

Key words: Interleukin- $1 \beta$, interleukin 1 receptor, insulin secretion, pancreatic islets, RINm5F cells, insulin-dependent diabetes mellitus.
The clinical outbreak of insulin-dependent diabetes mellitus is preceded by a chronic autoimmune assault to the pancreatic Beta cells. It has been suggested that the cytokine interleukin-1 (IL-1) may be one of the main mediators of this autoimmune reaction [1]. Long-term in vitro exposure of rodent pancreatic islets, or insulinoma cell lines, to recombinant IL-1 $\beta$ (rIL-1 $\beta$ ) suppresses insulin production and release, and can lead to Beta-cell death [1-3].

Although the ultimate mechanism of action of rIL-1 $\beta$ on insulin-producing cells remains to be clarified, recent data suggest that the cytokine binds to specific surface receptors [4]. This is followed by activation of gene transcription and protein translation $[5,6]$ and, in the case of rat islets, progressive impairment of mitochondrial function or, in the case of mouse islets, decreased insulin mRNA and consequent decrease in proinsulin biosynthesis and insulin release [2].

The complexity of the putative molecular mechanism of action of IL-1 $\beta$ in the Beta-cells makes it difficult to envisage a way to protect these cells from the deleterious effects of IL-1. Probably the most feasible approach would be to block the binding of the cytokine to the Beta-cell re- ceptors. Recently, an interleukin-1 receptor antagonist protein (IRAP) has been purified, cloned and expressed in Escherichia coli [7]. IRAP blocks the type 1 IL-1 receptor, found on T cells and fibroblasts. In the present study we investigated the effects of IRAP on the rIL- $1 \beta$ actions on rat and mouse pancreatic islets, and on the rat insulinoma cell line RINm5F. We demonstrated that IRAP can protect these different insulin-producing cells from the suppressive effects of rIL-1 $\beta$. These data suggest that the Beta-cells possess type 1 IL-1 receptors, and open the possibility for in vivo tests of this compound in rodent models of spontaneous insulin-dependent diabetes mellitus.

\section{Materials and methods}

\section{Materials}

Human recombinant IL-1 $\beta$ (rIL-1 $\beta$ ) was kindly provided by Dr. S. Gillis (Immunex, Seattle, Wash., USA). The biological activity of rIL-1 $\beta$ was $5 \mathrm{U} / \mathrm{ng}$, as compared with an interim international standard rIL-1 $\beta$ preparation (NIBSC, London, UK). The concentra- 
Table 1. Effects of interleukin-1 receptor antagonist protein (IRAP) on recombinant interleukin- $1 \beta$-induced inhibition of insulin release during prolonged exposure $(48 \mathrm{~h})$ of rat islets to the cytokine

\begin{tabular}{llll}
\hline $\begin{array}{l}\text { rIL-1及 } \\
(\mathrm{ng} / \mathrm{ml})\end{array}$ & $\begin{array}{l}\text { IRAP } \\
(\mathrm{ng} / \mathrm{ml})\end{array}$ & $\begin{array}{l}\text { Insulin accumulation } \\
\text { in the culture medium } \\
(\mathrm{ng} / 10 \text { islets } \times 48 \mathrm{~h})\end{array}$ & $\begin{array}{l}\text { Glucose-stimulated } \\
\text { insulin release } \\
(\mathrm{ng} / 10 \text { islets } \times 60 \mathrm{~min})\end{array}$ \\
\hline 0 & 0 & $1311 \pm 100$ & $43 \pm 4$ \\
0 & 500 & $1412 \pm 35$ & $46 \pm 7$ \\
0 & 5000 & $1280 \pm 166$ & $37 \pm 4$ \\
5 & 0 & $200 \pm 42^{\mathrm{b}}$ & $5 \pm 1^{\mathrm{b}}$ \\
5 & 500 & $288 \pm 63^{\mathrm{b}}$ & $6 \pm 2^{\mathrm{b}}$ \\
5 & 5000 & $797 \pm 132^{\mathrm{a}}$ & $23 \pm 6^{\mathrm{a}}$ \\
\hline
\end{tabular}

Rat pancreatic islets were exposed to $\mathrm{rIL}-1 \beta(5 \mathrm{ng} / \mathrm{ml})$ and different concentrations of IRAP during a $48 \mathrm{~h}$ culture period. The islet response to acute stimulation with glucose $(16.7 \mathrm{mmol} / \mathrm{l})$ was studied immediately after the $48 \mathrm{~h}$ period. Data are means \pm SEM of 5-11 separate experiments, each performed in triplicate. ${ }^{a} p<0.05$ and ${ }^{b} p<0.001$ vs a control (untreated) group, using ANOVA

tions of rIL-1 $\beta$ used in the present study ( 5 or $10 \mathrm{ng} / \mathrm{ml}$ ) have been found to functionally suppress pancreatic islets and arrest the growth of the rat insulinoma cell line RINm5F without inducing widespread cell killing (data not shown). Recombinant human IRAP was prepared as recently described [7].

\section{Methods}

Pancreatic islets were isolated by collagenase digestion from adult male Sprague-Dawley rats bred in a local colony (Biomedical Centre, Uppsala, Sweden) or from adult male NMRI mice (Anticimex, Sollentuna, Sweden) [2, 6]. The rat insulinoma cell line RINm5F was originally obtained from Dr. Å. Lernmark, Copenhagen, Denmark, seven years ago. The rat and mouse islets were cultured free-floating in medium RPMI 1640 containing $11.1 \mathrm{mmol} / \mathrm{l}$ glucose and supplemented with $10 \%$ (volume/volume) of donor calf serum [2]. Growing RINm5F cells were trypsinized and subcultured in RPMI 1640 supplemented with $10 \%$ (volume/volume) fetal calf serum, as previously described [3].

Exposure of rat and mouse islets to rIL-1 $\beta$ was performed for 60-120 min in culture medium, as described above. Unless indicated, IRAP was always added 15-20 min before rIL-1 $\beta$. After exposure to rIL-1 $\beta$ and/or IRAP, the islets were washed in RPMI 1640, transferred to new culture dishes and maintained in culture medium for $12 \mathrm{~h}$ without any further additions before being functionally studied. In some experiments, rat islets or RINm5F cells were cultured for $48 \mathrm{~h}$ in the presence of both rIL-1 $\beta$ and IRAP before functional studies.

Insulin release, insulin accumulation in the medium, islet DNA and insulin content were determined as previously described $[2,6]$. Briefly, insulin release was studied in triplicate groups of 10 islets by a first hour incubation at $1.7 \mathrm{mmol} / \mathrm{l}$ glucose. The incubation medium, Krebs-Ringer bicarbonate buffer supplemented with $2 \mathrm{mg} / \mathrm{ml}$ bovine serum albumin and $10 \mathrm{mmol} / \mathrm{l}$ Hepes, was then gently removed and replaced by medium containing $16.7 \mathrm{mmol} / 1$ glucose and the incubation continued for a second $60 \mathrm{~min}$ period. For the determination of RINm5F cell growth, $1 \mu \mathrm{Ci} / \mathrm{ml}^{3} \mathrm{H}$-thymidine was added to the culture medium during the last $1 \mathrm{~h}$ of a $48 \mathrm{~h}$ culture in the presence of rIL-1 $\beta$ and IRAP, and thymidine incorporation measured as previously described [3].

\section{Statistical analysis}

Data were analysed by analysis of variance (ANOVA).

\section{Results and discussion}

One hour exposure of rat pancreatic islets to $10 \mathrm{ng} / \mathrm{ml}$ rIL-1 $\beta$ induced a $80 \%$ decrease in glucose-stimulated $(16.7 \mathrm{mmol} / \mathrm{l})$ insulin release $12 \mathrm{~h}$ after exposure to the cytokine (Fig. 1 a). These data are in good agreement with recent observations by us [6] and others [5], suggesting that a brief exposure of rat $[5,6$, present data] and mouse islets (present data, see below) to rIL-1 $\beta$ is sufficient to induce a long period of Beta-cell functional suppression. The presence of $10 \mathrm{ng} / \mathrm{ml}$ IRAP did not modify the suppressive effects of rIL-1 $\beta$, but IRAP concentrations in the range of 100 to $10000 \mathrm{ng} / \mathrm{ml}$ were able to completely block the effects of rIL- $1 \beta(p<0.001$ as compared to islets exposed to IIL-1 $\beta$ ). IRAP alone did not modify islet function. In these and the experiments described below (Figs. $1 \mathrm{a}, 1 \mathrm{~b}$ and Table 1) there were no differences in the basal insulin secretion at $1.7 \mathrm{mmol} / \mathrm{l}$ glucose among the various control and experimental groups. The pooled values at $1.7 \mathrm{mmol} / \mathrm{l}$ glucose of the control islets, cultured in the absence of $\mathrm{rIL}-1 \beta$ or IRAP, was $4.7 \pm 0.8 \mathrm{ng} / 10$ islets $\times 60 \mathrm{~min}(n=23)$. In a second series of experiments islets were exposed for $2 \mathrm{~h}$ to rIL-1 $\beta$, and IRAP

Insulin release $(\mathrm{ng} / 10$ islets $60 \mathrm{~min})$

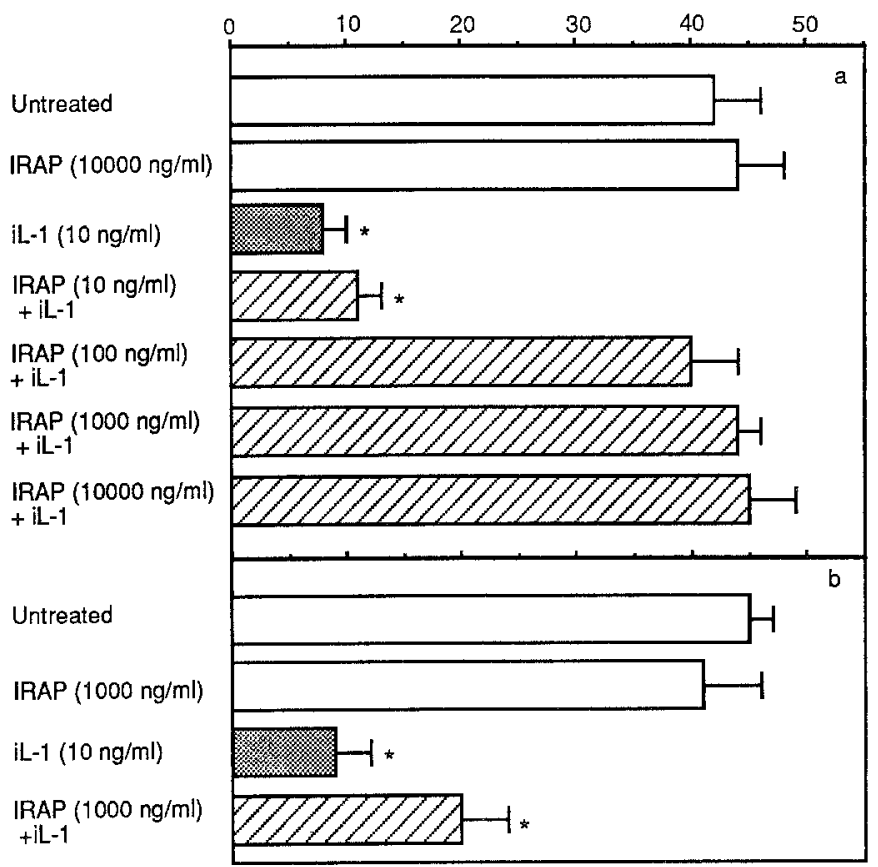

Fig. 1. a Dose-response effect of interleukin-1 receptor antagonist protein (IRAP) on the recombinant interleukin (rIL)-1 $\beta$-induced suppression of glucose-stimulated $(16.7 \mathrm{mmol} / \mathrm{l})$ insulin release. Rat islets were incubated for $1 \mathrm{~h}$ in the presence of $\mathrm{rIL}-1 \beta$ (IL-1, $10 \mathrm{ng} / \mathrm{ml}$ ) or different IRAP concentrations, washed and studied after $12 \mathrm{~h}$ in culture without any further additions to the medium. Data are means $\pm S E M$ of six separate experiments, each performed in triplicate. ${ }^{*} p<0.001$ vs control (untreated) group, using ANOVA. b Rat islets were incubated for $2 \mathrm{~h}$ in the presence of $10 \mathrm{ng} / \mathrm{ml} \mathrm{rIL}-1 \beta$ (IL-1). IRAP (1000 $\mathrm{ng} / \mathrm{ml})$ was added to the medium only during the second hour. The glucose-stimulated $(16.7 \mathrm{mmol} / \mathrm{l})$ insulin release was determined after $12 \mathrm{~h}$ in culture without any further additions. Data are means \pm SEM of five separate experiments, each performed in triplicate. $* p<0.001$ vs control (untreated) group, using ANOVA 
$(1000 \mathrm{ng} / \mathrm{ml})$ was added to the medium only during the second hour (Fig. 1b). After $12 \mathrm{~h}$, rIL-1 $\beta$ induced a similar $80 \%$ decrease in insulin release, as observed in Figure $1 \mathrm{a}$, and this effect was not significantly influenced by IRAP. These findings suggest that IRAP inhibit rIL- $1 \beta$ actions on Beta-cells by blocking surface receptor binding, and will be unable to counteract the effects of the cytokine once the initial binding and putative generation of intracellular signals have occurred.

In the short- and long-term experiments (see below) using rat islets there were no differences in DNA or insulin content among the different control and experimental groups. The pooled DNA and insulin content values for the control islets were $319 \pm 18 \mathrm{ng} \mathrm{DNA} / 10$ islets and $751 \pm 53 \mathrm{ng}$ insulin/10 islets $(n=23)$.

To evaluate the protective effects of IRAP against rIL$1 \beta$ under long-term culture conditions, rat islets were cultured in the presence of $\mathrm{rIL}-1 \beta(5 \mathrm{ng} / \mathrm{ml})$ and IRAP for $48 \mathrm{~h}$. Culture in the presence of high concentrations of IRAP did not affect islet function, as evaluated by insulin accumulation in the medium and the acute islet glucosestimulated insulin release (Table 1 ). rIL-1 $\beta$ inhibited both parameters by $75-90 \%$, and this effect was not counteracted by $500 \mathrm{ng} / \mathrm{ml}$ IRAP. By increasing the IRAP concentration to $5000 \mathrm{ng} / \mathrm{ml}$ a partial protection against the inhibitory effects of rIL-1 $\beta$ was observed $(p<0.05$ vs controls and $p<0.001 \mathrm{vs}$ rIL-1 $\beta$ ). In order to test if this relative lack of protection by IRAP over a $48 \mathrm{~h}$ period in culture was related to IRAP degradation, a new series of experiments was performed. Hence, rat islets were exposed to rIL-1 $13(5 \mathrm{ng} / \mathrm{ml})$ and IRAP $(500 \mathrm{ng} / \mathrm{ml})$ for $48 \mathrm{~h}$ and the medium changed every $12 \mathrm{~h}$ with the addition of fresh IRAP and rIL-1 $\beta$. Under these conditions rIL-1 $\beta$ again suppressed acute glucose-induced $(16.7 \mathrm{mmol} / \mathrm{ml})$ insulin release after $48 \mathrm{~h}$. The control islets released $46 \pm 4 \mathrm{ng}$ insulin $/ 10$ islets $\times 60 \mathrm{~min}$ and the rIL-1 $1 \beta$-treated islets $4 \pm 1 \mathrm{ng}$ insulin/ 10 islets $\times 60 \mathrm{~min}(n=4, p<0.001$ vs controls). IRAP completely counteracted the inhibitory action of rIL-1 $\beta$ on insulin release (IRAP + rIL-1 $\beta$ treated islets; $42 \pm 5 \mathrm{ng}$ insulin $/ 10$ islets $\times 60 \mathrm{~min}, n=4$, $p>0.2$ vs controls). Interestingly, when fresh rIL-1 $\beta$ was added every $12 \mathrm{~h}$ it induced a decrease in both islet DNA content (controls; $296 \pm 12$ ng DNA/10 islets and rIL-1 $\beta$ treated islets; $203 \pm 19 \mathrm{ng}$ DNA/10 islets, $n=4, p<0.01$ ) and islet insulin content (controls; $528 \pm 63 \mathrm{ng}$ insulin $/ 10$ islets and rIL-1 $1 \beta$-treated islets; $348 \pm 77 \mathrm{ng}$ insulin/10 islets, $n=4, p<0.02$ ). IRAP was again able to block these deleterious effects of rIL- $1 \beta$ (IRAP + rIL- $1 \beta$-treated islets; $261 \pm 16 \mathrm{ng}$ DNA/10 islets and $441 \pm 32 \mathrm{ng}$ insulin $/ 10$ islets, $n=4, p>0.05 \mathrm{vs}$ controls). Islet culture in the presence of IRAP alone did not affect islet function, insulin or DNA content (data not shown). These observations suggest that when fresh IRAP is added every $12 \mathrm{~h}$ it can protect the pancreatic islets from an $\mathrm{rIL}-1 \beta$ induced decrease in insulin release, DNA and insulin content over long periods in culture. It has been shown that IRAP is stable for up to 7 days at $37^{\circ} \mathrm{C}$ in the presence of RPMI 1640 plus $5-10 \%$ calf serum (Tracey et al., unpublished data). The present data nevertheless suggest that IRAP may not be stable under culture conditions in the presence of pancreatic islets.
A brief $(2 \mathrm{~h})$ exposure of mouse pancreatic islets to rIL-1 $13(10 \mathrm{ng} / \mathrm{ml})$ induced a similar suppression of glucose-induced $(16.7 \mathrm{mmol} / \mathrm{l})$ release after $12 \mathrm{~h}$ as observed in the rat islets. The control islets released $52 \pm 3 \mathrm{ng}$ insulin/10 islets $\times 60 \mathrm{~min}$ and the rIL-1 $\beta$-treated islets $16 \pm 5 \mathrm{ng}$ insulin $/ 10$ islets $\times 60 \mathrm{~min}(n=4, p<0.05)$. IRAP $(500 \mathrm{ng} / \mathrm{ml})$ was able to block this inhibitory effect of rIL$1 \beta$ (IRAP + rIL-1 $\beta$-treated islets; $41 \pm 7 \mathrm{ng}$ insulin/10 islets $\times 60$ min, $n=4, p>0.2$ vs controls and $p<0.05$ vs rIL$1 \beta$-treated islets). IRAP by itself did not interfere with the insulin release of the mouse islets (IRAP-treated islets; $45 \pm 3 \mathrm{ng}$ insulin $/ 10$ islets $\times 60 \mathrm{~min}$ ). Thus, mouse islet cells seem to possess similar IL-1 receptors as the rat islet cells.

The islets of Langerhans contain an heterogeneous cell population. Even considering that the prolonged preculture (5-7 days) before exposure to rIL-1 $\beta$ possibly eliminated most of the non-endocrine cells in the islets, it cannot be excluded that rIL-1 $\beta$ acted through generation of a secondary signal from non-Beta cells. If this is the case, the protective action of IRAP could be due to blocking an IL-1 receptor on non-Beta-cells. To address this issue, we tested the effects of $48 \mathrm{~h}$ exposure to rIL-1 $\beta(5 \mathrm{ng} / \mathrm{ml})$ and IRAP (5000 $\mathrm{ng} / \mathrm{ml}$ ) on an insulinoma cell line, RINm5F. As previously observed [3], rIL-1 $\beta$ induced a reduction of cell replication over a period of $48 \mathrm{~h}$ in culture. Hence, the $\left[{ }^{3} \mathrm{H}\right]$ thymidine incorporation in control RINm5F cells was $4708 \pm 222 \mathrm{dpm} / \mu \mathrm{g}$ DNA $\times 60 \mathrm{~min}$ and the $\mathrm{rIL}-1 \beta$-treated RINmF cells $3269 \pm 203 \mathrm{dpm} / \mu \mathrm{g}$ DNA $\times 60 \mathrm{~min}(n=6$, $p<0.01$ ). This effect was completely counteracted by IRAP (IRAP + rIL-1 $\beta$-treated cells; $4633 \pm 277 \mathrm{dpm} / \mu \mathrm{g}$ DNA $\times 60 \mathrm{~min} ; p<0.05$ vs rIL-1 $\beta$ ). IRAP by itself did not interfere with the RINm5F cell replication (IRAP-treated $\mathrm{RINm} 5 \mathrm{~F}$ cells; $5211 \pm 456 \mathrm{dpm} / \mu \mathrm{g}$ DNA $\times 60 \mathrm{~min})$. Culture of the RINm5F cells in the presence of rIL-1 $\beta$ induced a $15 \%$ decrease in DNA content per dish $(p<0.05$ vs controlRINm5F cells), and thiseffect was also counteracted by IRAP (data not shown). Together with the previous observations that a hamster insulin-producing cell line possesses specific receptors for rIL-1 [4], these findings suggest that both the rIL-1 $\beta$ actions and the protection induced by IRAP occurs through direct interactions with the Betacells, rather than via activation of other intermediary cells.

It has been suggested that naturally produced IRAP can be an IL-1 inhibitor, with the role of regulating and limiting in vivo certain IL-1 functions [7]. If this hypothesis is confirmed, it can explain why Beta-cell damage is not a common sequel of situations in which high serum levels of IL-1 are observed (e.g. septicaemia). Furthermore, two recent reports suggest that in vivo blocking of the IL-1 receptor can decrease the systemic inflammatory response to turpentine in mice [8] and protect against immune complex colitis in rabbits [9]. In this context, it is conceivable that IRAP may be a useful therapeutic agent for the early treatment of insulin-dependent diabetes. However, extensive studies on the effects of IRAP on the evolution of insulin-dependent diabetes in rodents must be performed to test the validity of this hypothesis.

Acknowledgements. We thank Ms. I.-B. Hallgren, Ms. E. Forsbeck, Ms. A. Nordin and Ms. S. Svanholm for their excellent technical assistance and Ms. A. Snellman for careful typing of the manuscript. 
This work was supported by grants from the Juvenile Diabetes Foundation International, the Swedish Medical Research Council $(12 \mathrm{X}-109 ; 12-8273 ; 12 \mathrm{X}-9237$ - connected to the " $\beta$-Cell Transplant, European Concerted Action of the Treatment of Diabetes"), the Swedish Diabetes Association, the Swedish Society of Medicine, the Nordic Insulin Fund, the Hoechst Diabetes Foundation, the Torsten and Ragnar Södeberg Foundation, the Magnus Bergvalls Stiftelse, the Family Ernfors Fund, the Danish Medical Research Council and the Danish Biotechnology Program.

\section{References}

1. Bendtzen K, Mandrup-Poulsen T, Nerup J, Dinarello CA, Svenson M, Nielsen JH (1986) Cytotoxicity of human pl 7 interleukin 1 for pancreatic islets of Langerhans. Science 232: 1545-1547

2. Eizirik DL, Welsh M, Strandell E, Welsh N, Sandler S (1990) Interleukin-1 $\beta$ depletes insulin messenger ribonucleic acid and increases the heat shock protein 70 in mouse pancreatic islets without impairing the glucose metabolism. Endocrinology 127: 2290-2297

3. Sandler S, Bendtzen K, Eizirik DL, Sjöholm A, Welsh N (1989) Decreased cell replication and polyamine content in insulin-producing cells after exposure to human interleukin $1 \beta$. Immunol Lett 22:267-272

4. Hammonds P, Beggs M, Beresford G, Espinal J, Clarke J, Mertz RJ (1990) Insulin-secreting $\beta$-cells possess specific receptors for interleukin-1 $\beta$. FEBS Lett 261: 97-100

5. Hughes JH, Colca JR, Easom RA, Turk J, McDaniel ML (1990) Interleukin-1 inhibits insulin secretion from isolated rat pancre- atic islets by a process that requires gene transcription and mRNA translation. J Clin Invest 86: 856-863

6. Eizirik DL, Bendtzen K, Sandler S (1991) Short exposure of rat pancreatic islets to interleukin- $1 \beta$ induces a sustained but reversible impairment in $\beta$-cell function. This effect is influenced by protease activation, gene transcription and protein synthesis. Endocrinology 128: 1611-1616

7. Carter DB, Deibel MR, Dunn CJ et al. (1990) Purification, cloning, expression and biological characterization of an interleukin-1 receptor antagonist protein. Nature 344: 633-638

8. Gershenwald JE, Fong Y, Fahey III TJ, Calvano SE, Chizzonite R, Killian PL, Lowry SF, Moldawer LL (1990) Interleukin 1 receptor blockade attenuates the host inflammatory response. Proc Natl Acad Sci (USA) 87: 4966-4970

9. Cominelli F, Nast CC, Clark BD, Schindler R, Llerena R, Eysselein VE, Thompson RC, Dinarello CA (1990) Interleukin 1 (IL-1) gene expression, synthesis, and effect of specific IL-1 receptor blockade in rabbit immune complex colitis. J Clin Invest 86: 972-980

Received: 2 January 1991

Dr. D. L. Eizirik

Department of Medical Cell Biology

Biomedicum

P. O. Box 571

Uppsala University

S-751 23 Uppsala

Sweden 